\title{
A Comprehensive Review of Our Current Understanding of Red Blood Cell (RBC) Glycoproteins
}

\author{
Takahiko Aoki \\ Laboratory of Quality in Marine Products, Graduate School of Bioresources, Mie University, \\ 1577 Kurima Machiya-cho, Mie, Tsu 514-8507, Japan; aoki@bio.mie-u.ac.jp; Tel.: +81-59-231-9569; \\ Fax: +81-59-231-9557
}

Received: 18 August 2017; Accepted: 24 September 2017; Published: 29 September 2017

\begin{abstract}
Human red blood cells (RBC), which are the cells most commonly used in the study of biological membranes, have some glycoproteins in their cell membrane. These membrane proteins are band 3 and glycophorins A-D, and some substoichiometric glycoproteins (e.g., CD44, CD47, Lu, Kell, Duffy). The oligosaccharide that band 3 contains has one N-linked oligosaccharide, and glycophorins possess mostly O-linked oligosaccharides. The end of the O-linked oligosaccharide is linked to sialic acid. In humans, this sialic acid is $\mathrm{N}$-acetylneuraminic acid (NeuAc). Another sialic acid, $\mathrm{N}$-glycolylneuraminic acid (NeuGc) is present in red blood cells of non-human origin. While the biological function of band 3 is well known as an anion exchanger, it has been suggested that the oligosaccharide of band 3 does not affect the anion transport function. Although band 3 has been studied in detail, the physiological functions of glycophorins remain unclear. This review mainly describes the sialo-oligosaccharide structures of band 3 and glycophorins, followed by a discussion of the physiological functions that have been reported in the literature to date. Moreover, other glycoproteins in red blood cell membranes of non-human origin are described, and the physiological function of glycophorin in carp red blood cell membranes is discussed with respect to its bacteriostatic activity.
\end{abstract}

Keywords: red blood cell; glycoproteins; biological function; glycophorin; band 3; O-linked oligosaccharides; $\mathrm{N}$-acetylneuraminic acid; $\mathrm{N}$-glycolylneuraminic acid

\section{Introduction}

The blood of mammals, such as humans, as well as of birds, reptiles, and teleosts, contains red blood cells (erythrocytes). Human red blood cells, which are the most commonly studied by researchers, are approximately $7 \mu \mathrm{m}$ in diameter, and their centre has a dented discoid shape.

Studies on biological membranes normally use human red blood cells (RBC) because these erythrocytes have no nuclei and are easy to obtain for cell membrane preparation. For the preparation of membrane proteins, it is necessary to solubilize the phospholipid bilayer by using detergents. Fairbanks et al. [1] developed a method in which red blood cell membranes were solubilized by sodium dodecyl sulfate (SDS), and then the extracted membrane proteins were separated by acrylamide gel electrophoresis (SDS-PAGE). As a result, membrane proteins and glycoproteins could be detected on SDS gels. Figure 1 shows the typical human red blood cell membrane proteins separated by SDS-PAGE using the method of Laemmli [2], which was later improved by Fairbanks et al. [1]. Table 1 depicts the nomenclature of each cell membrane protein according to Fairbanks et al. [1], along with apparent molecular mass $(\mathrm{kDa})$ and physiological function. Band 3, band 4.1, and band 4.2 are called the designated names at present. 


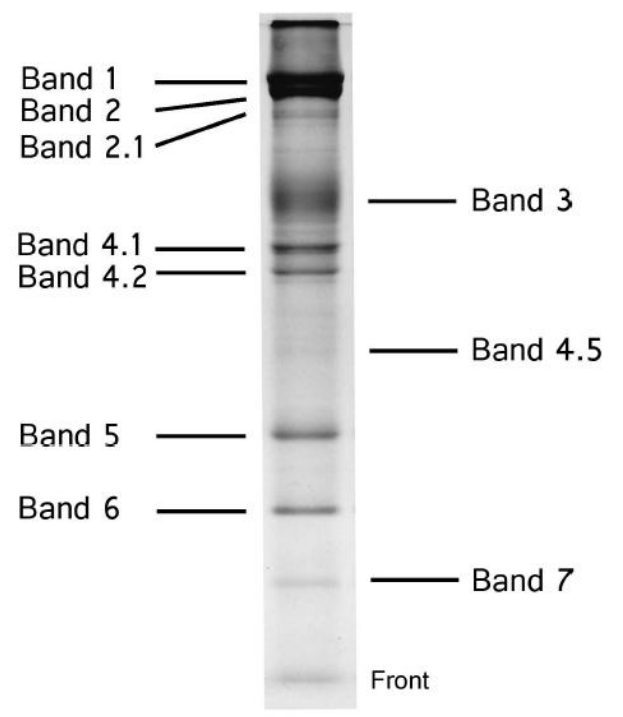

Figure 1. Sodium dodecyl sulfate (SDS)-polyacrylamide gel electrophoresis of human red blood cell (RBC) membranes. Healthy human RBC membranes stained with Coomassie brilliant blue. Electrophoresis was performed according to the method of Laemmli [2].

Table 1. Red blood cell membrane proteins.

\begin{tabular}{|c|c|c|c|}
\hline Band & Molecular Mass (kDa) & Designation & Function \\
\hline 1 & 240 & spectrin ( $\alpha$ chain $)$ & \multirow{3}{*}{ components of cytoskeleton } \\
\hline 2 & 220 & spectrin ( $\beta$ chain) & \\
\hline 2.1 & 210 & ankylin & \\
\hline 3 & 100 & band 3 (AE1) & anion transporter \\
\hline 4.1 & 82 & band 4.1 & \multirow{2}{*}{ components of cytoskeleton } \\
\hline 4.2 & 76 & band 4.2 & \\
\hline 4.5 & 55 & band 4.5 (GLUT1) & glucose transporter \\
\hline 5 & 43 & actin & components of cytoskeleton \\
\hline 6 & 35 & glyceraldehyde-3-phoshate dehydrogenase (GAPDH) & glycolytic enzyme \\
\hline 7 & 31 & stomatin & - \\
\hline
\end{tabular}

Band 3 is a glycoprotein and is detected as a diffuse band on SDS gel due to the microheterogeneity of the attached oligosaccharides [3]. Band 3 is detectable on the SDS gel by using protein staining with Coomassie Brilliant Blue (CBB) because band 3 has a small amount of oligosaccharides. Band 3 contains approximately $7 \%$ carbohydrate and contributes to approximately $10 \%$ of the total membrane carbohydrate [4]. By contrast, the sialooligosaccharide-rich glycoproteins are detectable by staining with the periodic acid-Schiff's (PAS) reagent $[1,5]$. The glycoproteins detected by PAS staining are called glycophorins. Figure 2 shows the nomenclature of human red cell membrane sialoglycoproteins. The designation of glycophorins is confusing because different nomenclatures have been used by different researchers. In the first part of the 1970s, the glycophorins were called as PAS 1-4 and, at present, they are termed glycophorins A-D, respectively [6]. Glycophorin $\alpha$ is the same as glycophorin A, and glycophorin $\delta, \beta$, and $\gamma$ are glycophorins $B, C$, and $D$, respectively [6-8].

Glycophorin A (dimer) is observed below band 3 on SDS-polyacrylamide gels (Figure 2), is a major component of red cell membrane glycoproteins, and is reported to have an apparent molecular mass of 29 [9] to $36 \mathrm{kDa}[10,11]$.

The electrophoretic migration of glycophorin is relatively low when compared to other membrane components because glycophorin is heavily glycosylated. Although the molecular mass of the other membrane proteins can estimated by migration on SDS-PAGE, the molecular mass of each glycophorin cannot be estimated in this manner. 


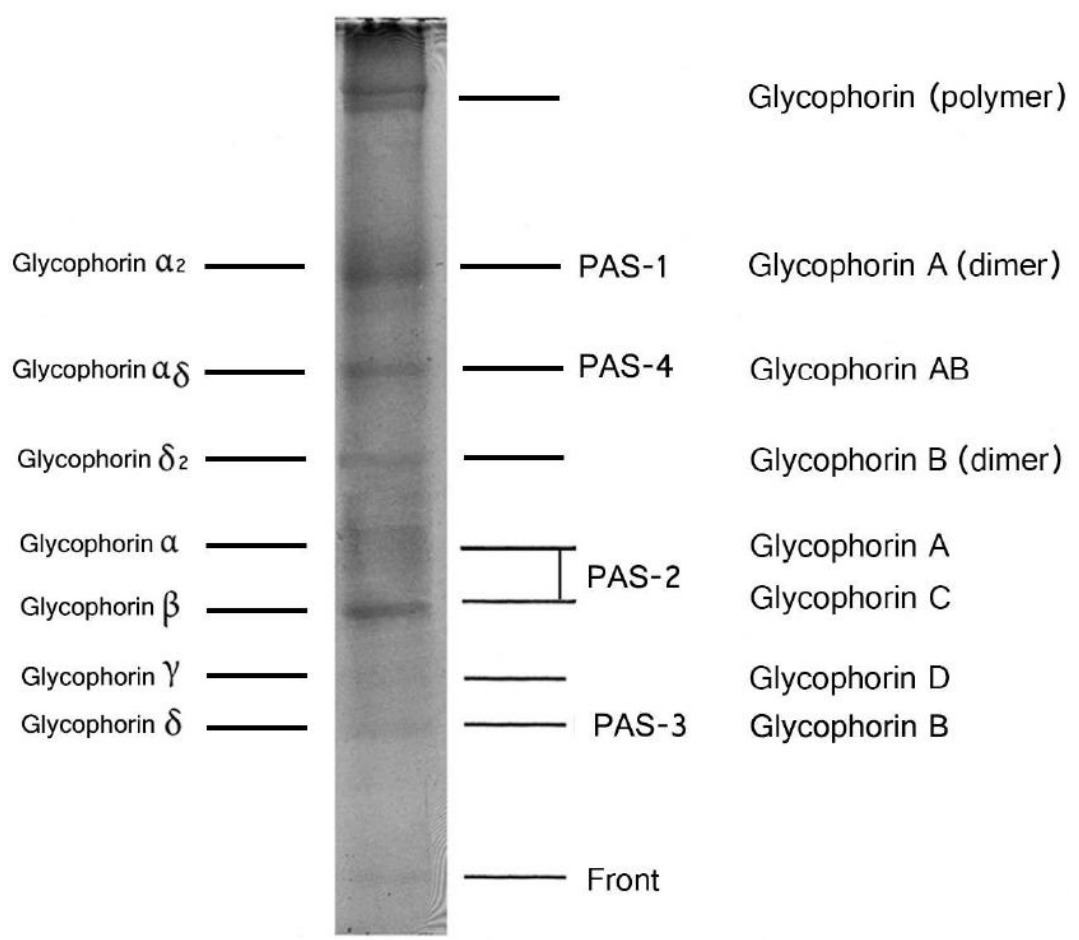

Figure 2. SDS-polyacrylamide gel electrophoresis of human red blood cell (RBC) membranes. Healthy human RBC membranes stained with periodic acid-Schiff (PAS) stain [1]. Electrophoresis was performed according to the method of Laemmli [2].

\section{Structure of the Human Red Blood Cell Membrane}

Red blood cell membrane proteins [12-14] can be classified into transmembrane proteins and peripheral membrane proteins that associate with the cytoplasmic side of the lipid bilayer. Band 3 and glycophorins are transmembrane proteins. Transmembrane proteins associate with the peripheral proteins that constitute the protein meshwork (cytoskeleton). Figure 3 shows a schematic drawing of the site of band 3 and glycophorins in human red blood cell membrane structure, with reference to the review on the red cell membrane skeleton $[14,15]$. The main component of the cytoskeleton is a spectrin tetramer. Its ends are linked by binding to the actin filament and band 4.1, and it forms a junctional complex. These junctions are linked to the end of some spectrin tetramers and form a netlike meshwork.

The N-terminal cytoplasmic domain of band 3 attaches to an intracellular protein (ankyrin), which binds to a spectrin tetramer. By connecting band 3 to ankyrin, band 3 links the cytoskeleton through the spectrin network. This cytoskeleton enables deformability and thereby maintains the integrity of the biconcave-shaped red blood cells.

Glycophorins $\mathrm{C}$ and $\mathrm{D}$ are linked to the band 4.1 protein and connect the cytoskeleton structure [16-19]. Glycophorins C, D, and band 3 are associated with the cytoskeleton, and the maintenance of shape and mechanical properties of the red blood cell after passing through capillary vessels [20].

This information indicates that glycophorins $\mathrm{C}$ and $\mathrm{D}$ are anchored to the membrane by the cytoskeleton. In contrast, there is only one report that glycophorin A connects to band 4.1 protein [21]. It is believed that glycophorins A and B are not associated with the cytoskeleton, thus enabling them to be easily released from the red cell membrane. 


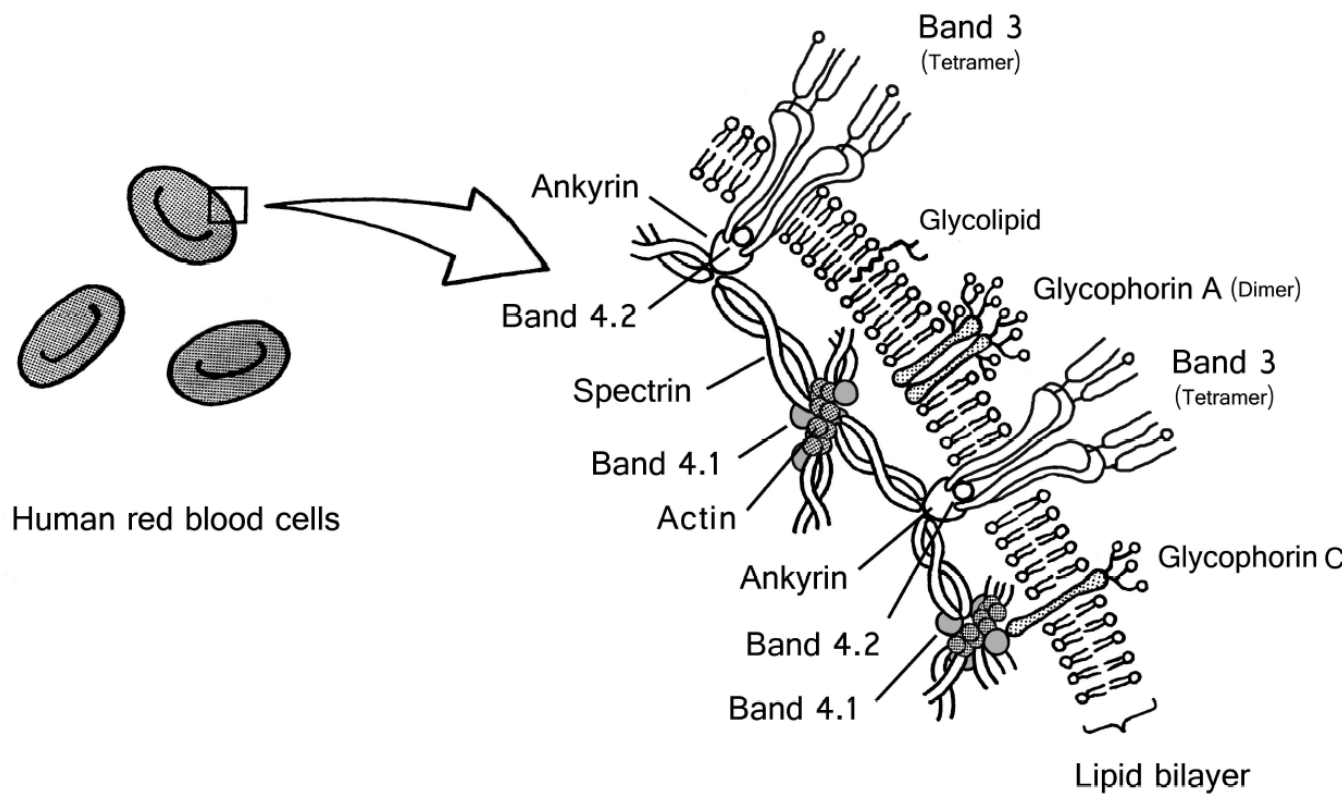

Figure 3. Illustration showing the location of band 3 and glycophorins in human red blood cell membranes. This illustration is based on several reviews [14,15,22]. According to Lux [14], the location of substoichiometric proteins (e.g., CD44, CD47, Lu, Kell, Duffy) remains unclear. In this illustration, these glycoproteins are omitted, the actin junctional complex (4.1R complex) is simplified, and the topology of band 3 and glycophorins is defined.

\section{Structure of Band 3}

The band 3 protein $[3,23]$ is the most abundant of the red cell membrane proteins and composes approximately $25 \%$ of these proteins. For Band 3, approximately $1.0 \times 10^{6}$ copies are present in each red blood cell. The molecular mass of band 3 is estimated at approximately $100 \mathrm{kDa}$ by SDS-PAGE. By mild proteolysis, the band 3 protein, which consists of 911 amino acid residues, can be divided into a hydrophilic cytoplasmic fragment of $41 \mathrm{kDa}$ and a hydrophobic membrane fragment of $52 \mathrm{kDa}$ [24]. It forms a dimer or tetramer in the phospholipid bilayer, and this complex connects to the cytoskeleton through ankyrin.

The elongated part of the $\mathrm{N}$-terminal domain facing the cytosol consists of a hydrophilic domain whose ends connect to the hydrophobic domain, and this unit crosses the membrane several times. The number of passes of the polypeptide unit has been established, and there may be 14 membrane spans based on cDNA analysis. The C-terminal domain is assumed to be on the cytoplasmic side of the membrane; however, the physiological function of this domain remains unclear.

Recently, the crystal structure of the band 3 anion exchanger domain has been analysed in detail [25]. Band 3 is composed of amino peptides and a single N-linked oligosaccharide, and the molecular mass of the carbohydrate is approximately $8 \%$ of band 3 . This $\mathrm{N}$-linked oligosaccharide is linked at Asn-649, which is located at a site approximately 28 amino acids from the C-terminus of the band 3 polypeptide. This oligosaccharide is exposed on the external side of the membrane and is heterogeneous in size on different band 3 molecules, as determined by the number of repeating $N$-acetyllactosamine units (Gal $\beta 1 \rightarrow 4$ GlcNAc $\beta 1 \rightarrow 3$ ) [26] (Figure 4). The end of the band 3 oligosaccharide is linked to sialic acid. This sialic acid is $\mathrm{N}$-acetylneuraminic acid (5-acetamido-3,5-dideoxy- $\alpha$-D-glycero-D-galacto-2-nonulopyranosidonic acid; Neu5Ac, NeuAc, NANA) and occurs broadly in humans [27]. 

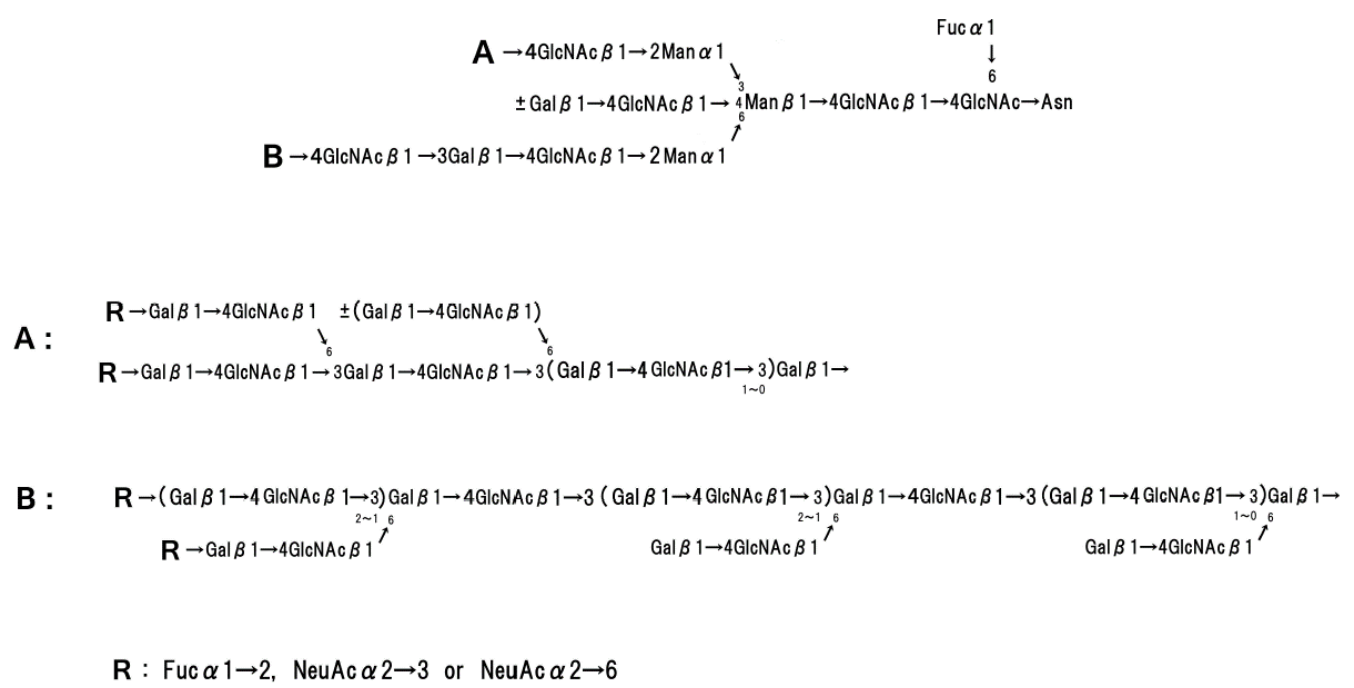

Figure 4. N-linked oligosaccharides of human band 3.

\section{Structure of Human Glycophorins}

Glycophorins [10,28] A and B represent approximately $85 \%$ and $10 \%$ of the PAS-positive membrane components, respectively, whereas, glycophorins $\mathrm{C}$ and $\mathrm{D}$ are minor species, contributing only $4 \%$ and $1 \%$ to the PAS-positive components, respectively [29].

For the major sialo-glycoprotein, glycophorin $\mathrm{A}$, it was deduced that $5 \times 10^{5}-10 \times 10^{5}$ copies are present in each red blood cell [30], which corresponds to $1.6 \%$ of the total human red blood cell proteins [31]. By contrast, $0.2 \times 10^{5}-1.0 \times 10^{5}$ copies of glycophorin B are present [32]. Glycophorin A consists of 131 amino acid residues as a single polypeptide chain [33] and contains 16 oligosaccharides attached to the N-terminus, accounting for a third of the molecule [34].

Glycophorin A homodimerizes in the red cell membrane [35-37], and this molecular structure has been analysed using NMR [38,39], polarized FTIR [40], and FRET measurements [41]. Glycophorin A is comprised of two motifs, an N-terminal moiety on the extracellular surface and a tethered C-terminal moiety, which consists of an $\alpha$-helix (hydrophobic transmembrane domain) and a hydrophilic cytoplasmic domain. Glycophorin A is surrounded by approximately 34 phospholipids [42]. Fifteen O-linked oligosaccharide chains and a single N-linked oligosaccharide chain are attached to the extracellular N-terminal moiety. Figures 5 and 6 show the basic structure of each oligosaccharide. The basic structure of the O-linked oligosaccharide consists of two NeuAc, Gal, and GalNAc, which form a tetra-saccharide, and the terminal GalNAc residue is attached to The/Ser of the polypeptide chain [43-45]. The basic structure of the N-linked oligosaccharide consists of NeuGc, Gal, Man, Fuc, and GlcNAc, and the terminal GlcNAc residue is attached to Asp 26 of the glycophorin polypeptide [46]. The amount of sialic acid contained in glycophorin A corresponds to approximately $75 \%$ of the total sialic acid of the red blood cell membrane [47].

$$
\text { NeuGc } \alpha 2 \rightarrow 3 \text { Gal } \beta 1 \rightarrow 3 \text { GalNAc } \rightarrow \text { Thr } / \text { Ser }
$$

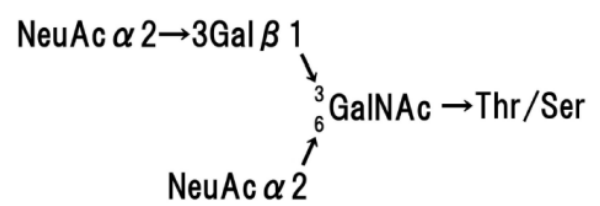

Figure 5. Basic structure of O-linked oligosaccharides of glycophorin A. 

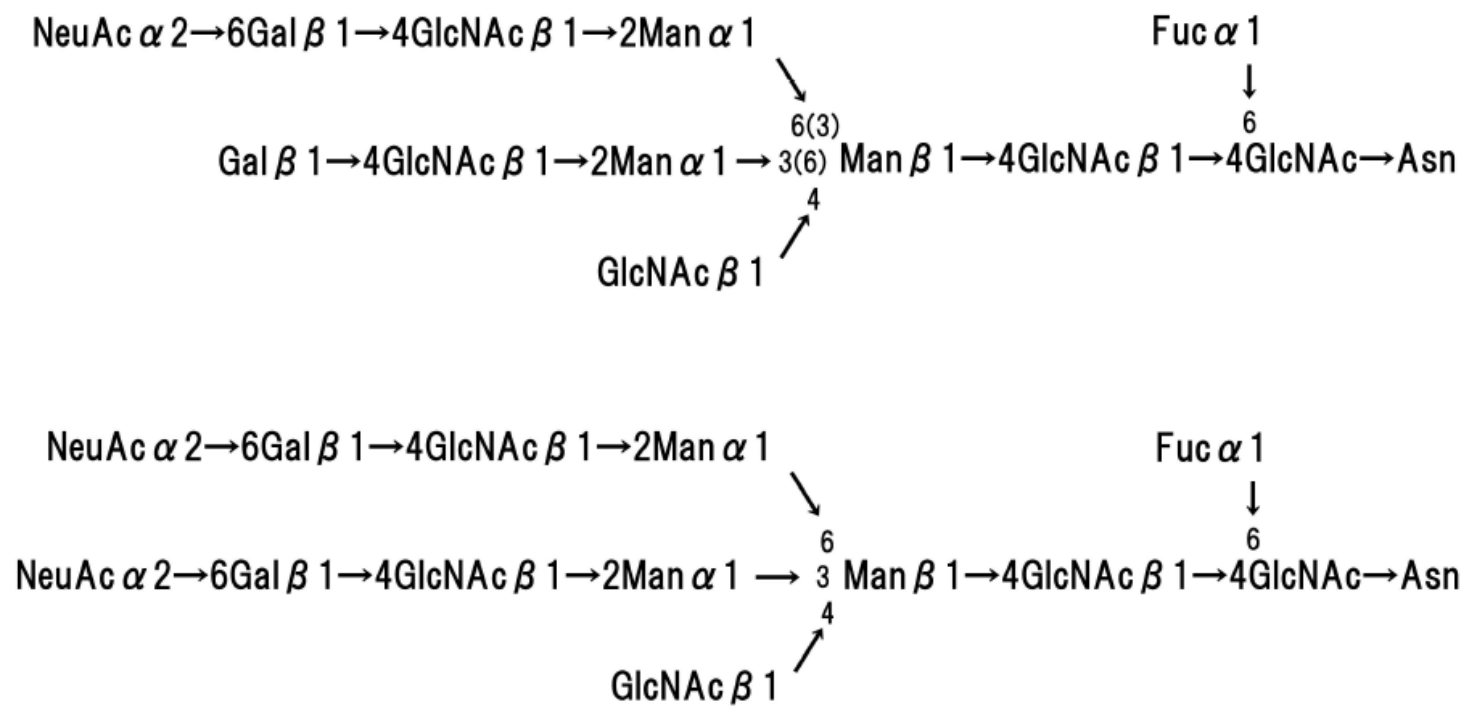

Figure 6. Basic structure of N-linked oligosaccharides of glycophorin A.

Glycophorin B was isolated by Furthmayr et al. [31,48] using the lithium diiodosalicynate (LIS)-phenol method [49]. The molecular mass of glycophorin B is estimated at approximately $20 \mathrm{kDa}$, and the sequence of $\mathrm{N}$-terminal domain is identical to that of glycophorin $\mathrm{A}[11,50]$ because both of the glycophorins are generated from the same gene cluster [51-53]. Glycophorins C and D are also generated from the same glycophorin gene cluster, and their molecular weights are estimated at approximately $32 \mathrm{kDa}$ and approximately $23 \mathrm{kDa}$, respectively [54,55]. Glycophorins $\mathrm{C}$ and $\mathrm{D}$ have been deduced to occur at approximately $5.0 \times 10^{4}-10 \times 10^{4}$ and approximately $2.0 \times 10^{4}$ copies in each red blood cell, respectively [56].

Glycophorin B has no N-linked oligosaccharide and 11 O-linked oligosaccharides bound to the protein moiety; glycophorin $\mathrm{C}$ has a single $\mathrm{N}$-linked oligosaccharide and $12 \mathrm{O}$-linked oligosaccharide chains; and, glycophorin D contains six O-linked chains [56,57]. The structures of the oligosaccharides of the other glycophorins are similar to those of glycophorin A [48]. In 1990, a gene for a fifth glycophorin (glycophorin E) was identified by the isolation of genomic clones, and its nucleotide sequence is almost identical to that of the glycophorin $B$ gene $[58,59]$. However, the expression and the function of glycophorin E have not been clarified [60].

\section{Other Glycoprotein in the Human Red Blood Cell Membrane}

Although they have not been detected by PAS staining of SDS-PAGE gels, some glycoproteins in human red blood cell membranes have been identified by using monoclonal antibodies.

There are reports that a band 4.5 protein (GLUT1) contains N-glycan, and increasing the $\mathrm{N}$-glycosylation of GLUT1 may influence its function as a glucose transporter [61].

The Na-H exchanger (NHE1), which associates with actin-binding proteins (ERM: ezrin, radixin, and moesin), contains both N-linked and O-linked oligosaccharides [62]. Its isoform, NHE2, has only O-linked oligosaccharides [63]. However, glycosylation of NHFs had no apparent effect on the rate of ion exchange [64]. CD44 and CD47 are also glycoproteins. The former binds to protein band 4.1 (4.1R), and the latter binds to band 4.2 (protein 4.2) and to the ankyrin-linked band 3 complex [14]. In non-erythroid cells, CD44 binds directly to ERM proteins [65]. CD44, which is involved in cell-cell communication, is known to be the cell surface receptor for hyaluronan (HA) and contains $N$-glycans, O-glycans, and glycosaminoglycans [66]. It has been reported that the glycosylation of CD44 affects its HA affinity [67,68]. CD47, which is also involved in cell-cell communication, carries $N$-glycans [69] but does not require glycans to interact with signal regulatory protein $\alpha(\operatorname{SIRP} \alpha)$ [70]. The physiological 
function of these glycans seems to be providing structural integrity, similar to LPS attached to the outer cell membranes of gram-negative bacteria.

In addition to glycophorins, several glycoproteins in human red cell membranes have blood group antigens [71]. DARC/Duffy blood group antigens have been reported in proteins that contain $\mathrm{N}$-glycan [72] and in the receptor for the malaria parasite [73]. Lu (Lutheran) blood antigen, which enables binding to $\alpha$-spectrin, appears to contain small amounts of both $\mathrm{N}$-glycan and O-glycan [74]. These glycans are affected by the expression of $\mathrm{Lu}^{\mathrm{b}}$ antigenic activity [75]. Although present in only small amounts, the Kell blood group is a major antigenic system in human RBCs, and it interacts with band 3 protein [76]. This antigen is carried by a $93 \mathrm{kDa}$ glycoprotein, and it has six N-linked polysaccharides that do not contain NeuAc $[77,78]$. However, the physiological function of Kell antigen is related to its amino acid composition, not polysaccharides [79], in contrast to I blood type antigen (the poly- $\mathrm{N}$-acetyllactosamine structure) [80]. The diversity of blood group antigens, as mentioned above, which is lacking in carp sera (in the Section 9), may be related to the existence of various anti-carbohydrate antibodies in human sera [81]. Researchers are interested in the reactions of these antibodies with oligosaccharides containing mainly NeuAc, Gal, and Fuc at the termini of polysaccharides, but these antibodies do not react with Man, which is the primary component of N-glycan.

\section{Physiological Function of Band 3}

Band $3[3,82-84]$ is well known to function as an anion exchanger. When red blood cells pass through the lung blood vessels, band 3 protein has a function in collecting $\mathrm{CO}_{2}$ from human tissues in exchange for $\mathrm{Cl}^{-}$as the form of $\mathrm{HCO}_{3}{ }^{-}$. Moreover, such an anion exchange function is also involved in $\mathrm{pH}$ regulation within cells. There are several reports on the band 3-like membrane protein having these functions in various cell membranes [84,85].

The role of the N-linked oligosaccharide of band 3 has not been established. There is a report that the oligosaccharide of band 3 does not affect the anion transport function in red blood cells [86]. Other reports indicate a role for the oligosaccharide as an antigen, and these reactions are related to the ageing phenomenon [87-89]. In this reaction, when the red cell membrane is damaged by oxidation through the ageing process, the localization of band 3 changes to bind anti-band 3 IgG (senescent antigen), and this binding site is at the oligosaccharide that has terminal NeuAc residue. The anti-band $3 \mathrm{IgG}$ that binds band 3 is recognized in the spleen by macrophages, and macrophage autolysis digests the senescent red blood cell [90-93]. However, other reports demonstrate that the anti-band $3 \operatorname{IgG}$ was bound to the band 3 protein itself, not the carbohydrate moieties [94,95].

\section{Physiological Function of Human Glycophorins}

Glycophorins $[30,96]$ are extracted from red cell membrane preparations in the aqueous phase using organic solvents with some detergents because of their high content of sialic acid and highly hydrophobic protein moiety. Several organic solvents have been used as extract solutions, mainly chloroform/methanol [97], pyridine [98], and LIS-phenol [49]. The obtained glycophorin preparation is highly prone to aggregate, even in the presence of SDS [99-102]. Glycophorin A (PAS 1) forms a dimer in the SDS gel in SDS-PAGE [100,103,104]. Moreover, it forms a polymer [50] or hybridizes with glycophorin B (PAS-4, $\alpha-\delta$-glycophorin) $[105,106]$. This dimerization is caused by the $\alpha$-helix of the transmembrane domain of glycophorin A interacting with another glycophorin in the intact red cell membrane [37,40]. Glycophorin B also forms a dimer, similar to glycophorin A [18].

As mentioned above (in Section 2), glycophorins $C$ and $D$ are associated with the cytoskeleton and the maintenance of the shape and mechanical properties of red blood cells [21], and this function contributes to the negative surface charge caused by glycophorins containing sialic acid. Without its negative charge, the mobility of the red blood cell is greatly reduced [107].

The major glycophorin, glycophorin A, is a single polypeptide chain and is linked to several sialo-oligosaccharides, which carry some blood group antigens. These blood group antigens are 
located at the O-linked oligosaccharides and the nearby amino acid sequence of these oligosaccharides binding site. Glycophorin A carries the $\mathrm{M}$ and $\mathrm{N}$ blood group antigens, as determined by the amino acid sequence at residue 1 and residue 5 of the mature polypeptide (Ser1/Gly5 for M and Leu1/Glu5 for N). Glycophorin B, on the other hand, has only an N form, and its amino acid sequence is identical to that of N-type glycophorin A. Glycophorin B carries other blood group antigens, the Ss blood group, as determined by the amino acid sequences at Met 29 for $\mathrm{S}$ or Thr 29 for s specificity [108].

Both glycophorin polypeptides possess 3 O-linked oligosaccharides containing NeuAc linked at amino acid residues 2, 3, and 4. Both glycophorins lose blood group activities by desialylation treatment [109]. The Wright (Wr) antigens are also reported to be associated with band 3 and glycophorin A [110]. Glycophorin C and its shorter form, glycophorin D, are antigenically distinct from glycophorins A and B. Glycophorin C carries several blood group antigens (Gerbich, Yus, $\mathrm{Wb}, \mathrm{An}^{\mathrm{a}}$, and $\mathrm{Dh}^{\mathrm{a}}$, and others) [111-113]. Glycophorins are also reported to carry the ABH blood group antigens [114,115]. According to Podbielska et al. [116], O-linked oligosaccharides isolated from glycophorin A carried the A, B, or H blood group antigen. Although these oligosaccharides reacted with $\mathrm{ABH}$ blood group antigens, the reaction was estimated at a relatively low level. It is thought that the oligosaccharides containing Fuc are minor components in the total amount of oligosaccharides from glycophorin A.

Another physiological function of glycophorins involves the lectin receptors. Glycophorins are linked to several sialo-oligosaccharides, so several lectins, such as Psathyrella velutina lectin (PVL), wheat germ agglutinin (WGA), and others, interact with the oligosaccharide moiety of glycophorin [117-119].

Other functions of glycophorins as receptors are reported to be involved with the vital functions of interaction of red blood cells and the influenza virus [120,121], Sendai virus [122,123], malaria parasite [124-127], and Escherichia coli $\alpha$-haemolysin [128]. Although the relation between influenza virus and human red blood cells was known as early as the 1940s [129], there was difficulty proving this reaction because glycophorin is prone to aggregation, and the use of organic solvents and contaminating glycolipids in the purification process need to be considered. In the 1990s, the vital function became clear after the development of new experimental methods (e.g., using detergents [130], reconstruction of glycophorin-bearing liposome by using egg phosphatidylcholine [120], quick-freezing electron microscopy [121], and elastic light scattering [131]). Recently, experiments performed with stem cell lines revealed the interaction of glycophorin A with band 3 [132], and glycophorin C as a receptor for the rodent malaria parasite [133].

Several lines of evidence have suggested an interaction between glycophorin A and band 3 in their biosynthesis and processing [3,134]. However, glycophorin A knockdown had no effect on the cell surface expression of band 3 [110]. Moreover, glycophorin A-deficient red blood cells did not clearly demonstrate the physiological role of glycophorin A [135].

\section{Glycoproteins in Red Cell Membranes of Non-Human Origin}

Although glycoproteins in the human red cell membrane have been researched extensively, there are few reports on glycoproteins in other mammalian or avian red cell membranes. Some researchers have reported the electrophoretic patterns of mammalian red cell membranes (ox, horse, swine, sheep, goat, rabbit, guinea pig, rat, and mouse) [136,137]. According to these reports, these main membrane proteins are similar to those of human red cell membranes. Each membrane component (ankyrin, spectrin, band 3, band 4.1, and actin) was detected using SDS gels. The electrophoretic pattern of the cat red blood cell membrane (Felis catus) was also similar to that of human [138].

On the other hand, glycophorin patterns (PAS-stained band patterns) are different in humans [136], and these differences are caused by the component containing oligosaccharides. The glycophorins from horse [139], bovine [140], pig [141], and goat contain sialic acid as NeuGc ( $\mathrm{N}$-glycolylneuraminic acid), not as NeuAc [142]. While the sialic acid of dog [143] and mouse [144] is NeuAc, canine 
individuals containing only NeuGc have been reported. The monkey glycophorin demonstrates MN blood group activities and contains a single O-linked oligosaccharide that is composed of NeuGc, Gal, and GalNAc [145]. The core structural unit of these O-linked sialo-oligosaccharides from various mammalian sources is sialic acid $\alpha 2 \rightarrow 3 \mathrm{Gal} \beta 1 \rightarrow 3$ (sialic acid $\alpha 2 \rightarrow 6$ )GalNAc-ol or sialic acid $\alpha 2 \rightarrow[3 \mathrm{Gal} \beta 1 \rightarrow 4 \mathrm{GlcNac} \beta 1]_{n} \rightarrow 3 \mathrm{Gal} \beta 1 \rightarrow 3 \mathrm{GalNAc-ol} \mathrm{[146]} \mathrm{(Figure} \mathrm{7).}$

Horse : NeuGc $\alpha 2 \rightarrow 3$ Gal $\beta 1 \rightarrow 3$ GalNAc-0l

Rabbit : NeuAc $\alpha 2 \rightarrow 3$ Gal $\beta 1 \rightarrow 3$ GalNAc-ol

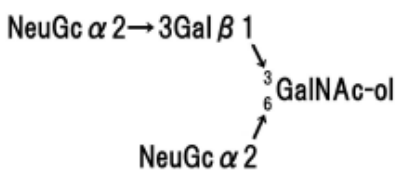

3Gal $\beta 1$

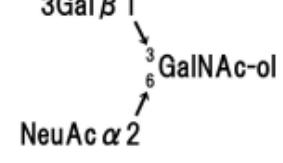

NeuAc $\alpha 2 \rightarrow 3$ Gal $\beta 1$

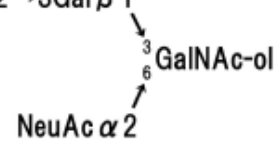

Chicken : $\operatorname{NeuAc} \alpha 2 \rightarrow 3$ Gal $\beta 1$

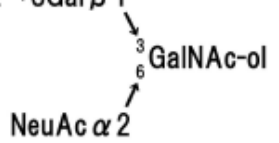

\section{Rat : $\quad$ NeuAc $\alpha 2 \rightarrow 3$ Gal $\beta 1 \rightarrow 3$ GalNAc-ol}

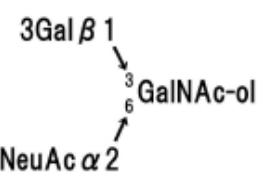

NeuAc $\alpha 2 \rightarrow 3$ Gal $\beta 1$

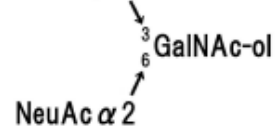

NeuAc $\alpha 2 \rightarrow 3$ Gal $\beta 1$

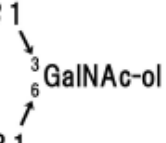

NeuAc $\alpha 2 \rightarrow 3 \mathrm{Gal} \beta 1 \rightarrow 4 \mathrm{GlcNAc} \beta 1$

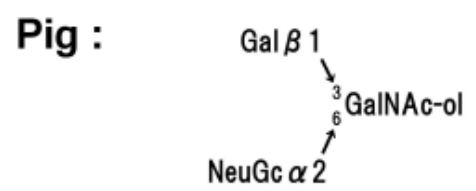

$\mathrm{Gal} \beta 1 \rightarrow 3 \mathrm{Gal} \beta 1 \rightarrow 4 \mathrm{GIcNAc} \beta 1 \rightarrow 3 \mathrm{Gal} \beta 1$

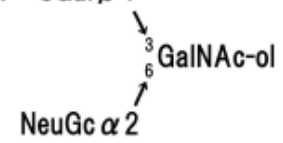

Carp :

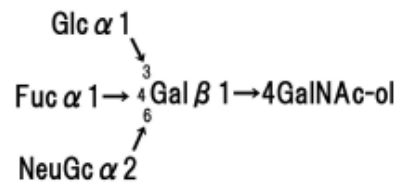

Figure 7. O-linked sialo-oligosaccharides of glycoproteins of mammalian, avian and teleost origins.

Non-mammalian red blood cell membranes have not been researched extensively. A major reason for this is that avian and teleost red blood cells contain a nucleus, and this causes difficulty during cell membrane preparation. The red blood cell membranes of pigeon [147], chicken [148], and turkey [149] for avian species and rainbow trout [150] for teleosts have been reported, and the main membrane proteins are similar to those of human red blood cells. Research on chicken band 3 [151] and rainbow trout band $3[152,153]$ has been reported, while detection of glycophorins (PAS-stained bands on SDS-gel) has been reported based on chicken membrane preparation, and the core structure of the O-linked oligosaccharide is the tetraose NeuAc $\alpha 2 \rightarrow 3$ Gal $\beta 1 \rightarrow 3$ (NeuAc $\alpha 2 \rightarrow 6$ )GalNAc-ol $[154,155]$ (Figure 7).

There were no reports on teleost glycophorin until Aoki et al. reported the detection of glycophorins in carp and rainbow trout red cell membranes [156]. 


\section{Glycophorin in Carp Red Blood Cell Membranes}

Aoki et al. reported the presence of glycophorins in red blood cell membranes of carp on SDS electrophoresis gels by PAS staining [156]. While membrane proteins from carp membrane preparations are similar to those of human red cell membranes, carp and trout showed different glycophorin patterns. The major glycophorin from carp membrane preparations is positioned near the human glycophorin A (dimer). According to the amino acid composition of carp glycophorin, there was no striking difference from that of human glycophorin A [157]. Although human glycophorins A and B carry the MN and Ss blood group antigens, it is unclear whether carp glycophorin carries these blood group antigens, as no blood group antigen reaction has been observed by titration (Aoki et al., unpublished materials).

The O-linked oligosaccharide of carp glycophorin exhibited bacteriostatic activity, and this activity is observed on all tested bacteria (Gram-positive bacteria: Micrococcus luteus and Bacillus subtilis, Gram-negative bacteria: Vibrio anguillarum, Edwardsiella tarda, Aeromonas hydrophila, Escherichia coli, and Pseudomonas fluorescens) $[157,158]$. In the blood of diseased carp infected by P. fluorescens, carp glycophorin is released from red blood cell membranes and interacts with the bacterium [158]. By electron microscopic observations, the released carp glycophorin molecule from the cell membrane attaches to the flagellum of $V$. anguillarum or the cell surface of M. luteus and inhibits bacterial growth [157].

These bacteriostatic activities are caused by the sialo-oligosaccharide from carp glycophorin and are attributed to the nature of the lectin receptor. It is thought that some lectin-like proteins exist on the surface of Gram-positive bacteria or the flagellum of Gram-negative bacteria. These observations indicate that carp glycophorin is released from red cell membranes and adsorbed onto the surface of invading bacteria in the blood (Figure 8).

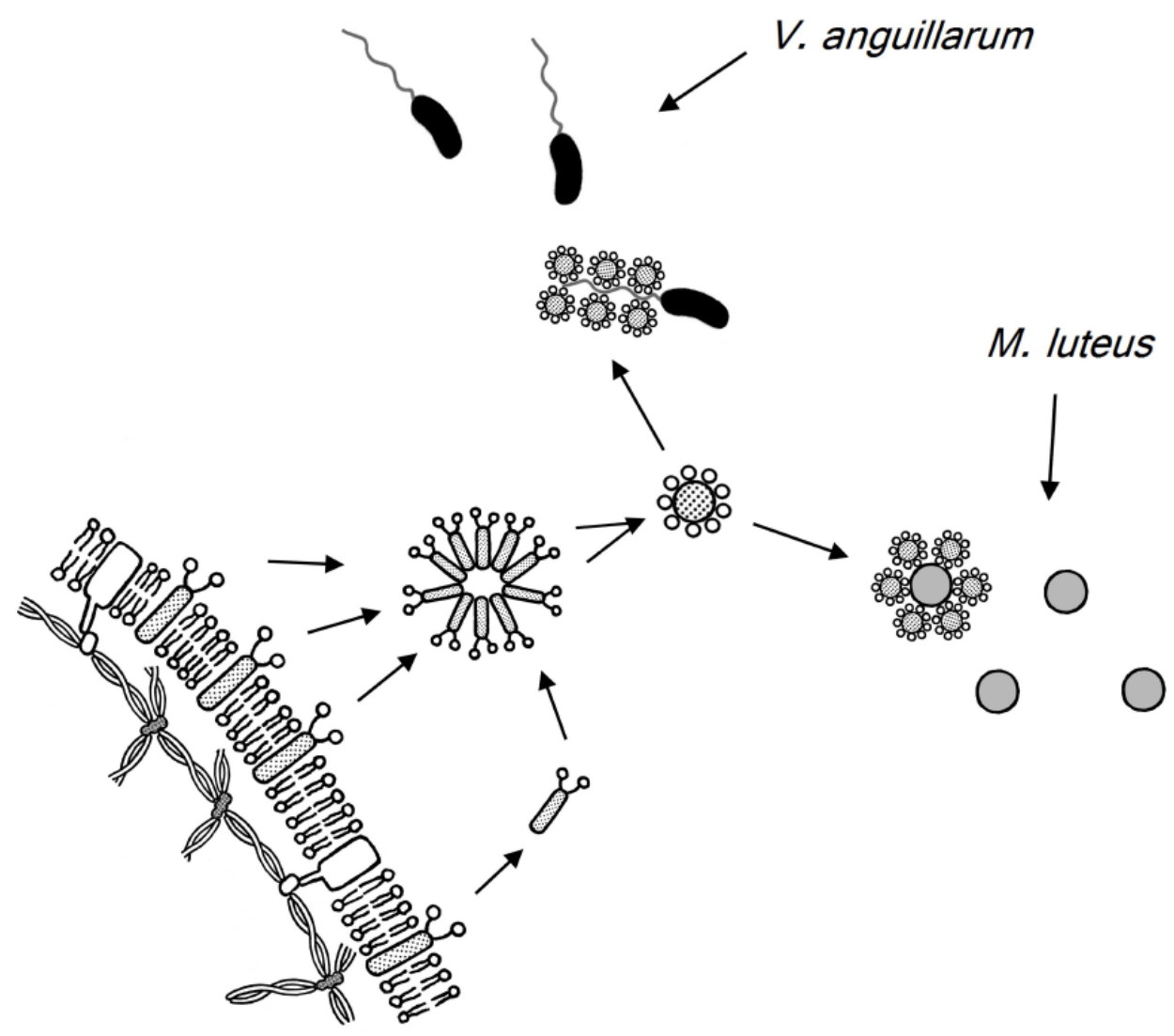

Figure 8. Schematic representation of the carp glycophorin interaction with invading bacteria in carp blood. 
In the Edo period of Japan, drinking carp blood was well known to the people as a folk remedy for tuberculosis. As tuberculous is caused by the bacterium (Mycobacterium tuberculosis), the bacteriostatic activity of carp glycophorin is suggested to relate to the efficacy of drinking carp blood.

The structure of the bacteriostatic sialo-oligosaccharide of carp glycophorin was determined as NeuGc $\alpha 2 \rightarrow 6$ (Fuc $\alpha 1 \rightarrow 4)($ Glc $\alpha 1 \rightarrow 3)$ Gal $\beta 1 \rightarrow 4$ GalNAc-ol [159] (Figure 7). The $1 \rightarrow 4$ linkage of GalNAc is unique as compared with other O-linked oligosaccharides of mammalian origin. Interestingly, the $\beta 1 \rightarrow 3$ glycosidic linkage of xylan, which is a component of seaweed cell walls, is unlike the standard $\beta 1 \rightarrow 4$ linkage of land plants [160]. It is possible to detect the $\beta 1 \rightarrow 4$ linkage of $\mathrm{N}$-acetylgalactosamine in marine organisms.

The sialo-oligosaccharides from carp glycophorin that have bacteriostatic activity are pentoses. This may be related to the finding that penta- or hexasaccharides obtained from chitin have bacteriostatic activity [161]. In the bacteriostatic reaction, it is supposed that the size of the oligosaccharide would correspond to the dimension of the cleft that occurs in the lectin-like protein, and might contribute to the charge of sialic acid. In teleost blood, IgG does not exist, and other antibodies exist in low levels [162]. It is suggested that glycophorin may exist as a substitute for antibodies in teleost blood. Although the physiological function of human glycophorin has not yet been clarified, the structure of the human glycophorin O-linked tetra oligosaccharide is a simpler form than that of the carp's pentose. It is considered that IgG became a major component in the human immune system and that the bacteriostatic activity of human glycophorins has been lost in the process of evolution.

\section{Conclusions}

The research on glycosylation of RBC membrane proteins has not been fully investigated when compared to the research on the protein moiety of RBC glycoproteins. Moreover, the target of research on $\mathrm{RBC}$ is mainly human blood. Although the preparation of human RBC membranes is relatively easy, the component of human RBC is more complicated than non-mammalian RBC, especially in regard to the blood group antigens.

On the contrary, the preparation of teleostei RBC membranes is fairly difficult because containing cell nucleus, the component of RBC is simpler than that of human. In particular, the glycosylation of carp RBC is simpler than that of human glycophorins A, B, C, and D. As mentioned above, accordingly, it is suggested that the collection of information on the non-mammalian RBCs leads the comprehension on the role of human RBC glycosylation.

Acknowledgments: The author is indebted to Atsushi Ooi, Mie University, for the preparation of this work. I am also grateful to Yasuko Mizuno, Toray Research Center, Inc. (Kamakura, Japan).

Conflicts of Interest: The author declares no conflict of interest.

\section{References}

1. Fairbanks, G.; Steck, T.L.; Wallach, D.F.H. Electrophoretic analysis of the major polypeptides of the human erythrocyte membrane. Biochemistry 1971, 10, 2606-2617. [CrossRef] [PubMed]

2. Laemmli, U.K. Cleavage of structural proteins during the assembly of the head of bacteriophage T4. Nature 1970, 227, 680-685. [CrossRef] [PubMed]

3. Tanner, M.J.A. Molecular and cellular biology of the erythrocyte anion exchanger (AE 1). Semin. Hematol. 1993, 30, 34-57. [PubMed]

4. Steck, T. The organization of proteins in the human red blood cell membrane: A review. J. Cell Biol. 1974, 62, 1-19. [CrossRef] [PubMed]

5. Doerner, K.C.; White, B.A. Detection of glycoproteins separated by nondenaturing polyacrylamide gel electrophoresis using the periodic acid-Schiff stain. Anal. Biochem. 1990, 187, 147-150. [CrossRef]

6. Anstee, D.J.; Tanner, M.J.A. Structure and function of the red cell membrane sialoglycoproteins. Br. J. Haematol. 1986, 64, 211-215. [CrossRef] [PubMed] 
7. Anstee, D.J.; Mawby, W.J.; Tanner, M.J.A. Abnormal blood-group-Ss-active sialoglycoproteins in the membrane of Miltenberger class III, IV and V human erythrocytes. Biochem. J. 1979, 183, 193-203. [CrossRef] [PubMed]

8. Owens, J.W.; Mueller, T.J.; Morrison, M. A minor sialoglycoprotein of the human erythrocyte membrane. Arch. Biochem. Biophys. 1980, 204, 247-254. [CrossRef]

9. Grefrath, S.P.; Reynolds, J.A. The molecular weight of the major glycoprotein from the human erythrocyte membrane. Proc. Nat. Acad. Sci. USA 1974, 71, 3913-3916. [CrossRef] [PubMed]

10. Fukuda, M. Molecular-genetics of the glycophorin A gene cluster. Semin. Hematol. 1993, 30, $138-151$. [PubMed]

11. Blanchard, D.; Dahr, W.; Hummel, M.; Lartron, F.; Beyreuther, K.; Cartron, J.-P. Glycophorins B and C from human erythrocyte membranes. Purification and sequence analysis. J. Biol. Chem. 1987, 262, 5808-5811. [PubMed]

12. Mohandas, N.; Chasis, J.A. Red blood cell deformability, membrane material properties and shape: Regulation by transmembrane, skeletal and cytosolic proteins and lipids. Semin. Hematol. 1993, 30, 171-192. [PubMed]

13. Bennet, V. The membrane skeleton of human erythrocytes and its implications for more complex cells. Ann. Rev. Biochem. 1985, 54, 273-304. [CrossRef] [PubMed]

14. Lux, S.E., IV. Anatomy of the red cell membrane skeleton: Unanswered questions. Blood 2016, 127, 187-199. [CrossRef] [PubMed]

15. Cordat, E.; Reithmeier, R.A.F. Structure, function, and trafficking of SLC4 and SLC26 anion transporters. Curr. Top. Membr. 2014, 73, 3-15.

16. Hemming, N.J.; Anstee, D.J.; Mawby, W.J.; Reid, M.E.; Tanner, M.J.A. Localization of the protein 4.1-binding site on human erythrocyte glycophorins C and D. Biochem. J. 1994, 299, 191-196. [CrossRef] [PubMed]

17. Hemming, N.J.; Anstee, D.J.; Staricoff, M.A.; Tanner, M.J.A.; Mohandas, N. Identification of the membrane attachment sites for protein 4.1 in the human erythrocyte. J. Biol. Chem. 1995, 270, 5360-5366. [CrossRef] [PubMed]

18. Reid, M.E.; Takakuwa, Y.; Conboy, J.; Tchernia, G.; Mohandas, N. Glycophorin C content of human erythrocyte membrane is regulated by protein 4.1. Blood 1990, 11, 2229-2234.

19. Alloisio, N.; Dalla Venezia, N.; Rana, A.; Andrabi, K.; Texier, P.; Gilsanz, F.; Cartron, J.-P.; Delaunay, J.; Chishti, A.H. Evidence that red blood cell protein p55 may participate in the skeleton-membrane linkage that involves protein 4.1 and glycophorin C. Blood 1993, 82, 1323-1327. [PubMed]

20. Staricoff, M.A.; Tanner, M.J.A. Role of band 3 and glycophorin $C$ in the maintenance of the shape and mechanical properties of the human red blood cell. Cell. Mol. Biol. Lett. 1996, 1, 151-161.

21. Lovrien, R.E.; Anderson, R.A. Glycophorin is linked by band 4.1 protein to the human erythrocyte membrane skeleton. Nature 1984, 307, 655-658.

22. Mohandas, N.; Gallagher, P.G. Red cell membrane: Past, present, and future. Blood 2008, 112, 3939-3948. [CrossRef] [PubMed]

23. Okubo, K.; Hamasaki, N. Recent progress on band 3 protein. Seikagaku 1992, 64, 1116-1120. (In Japanese) [PubMed]

24. Steck, T.L.; Koziarz, J.J.; Singh, M.K.; Reddy, G.; Köhler, H. Preparation and analysis of seven major, topographically defined fragments of band 3, the predominant transmembrane polypeptide of human erythrocyte membranes. Biochemistry 1978, 17, 1216-1222. [CrossRef] [PubMed]

25. Arakawa, T.; Kobayashi-Yurugi, T.; Alguel, Y.; Iwanari, H.; Hatae, H.; Iwata, M.; Abe, Y.; Hino, T.; Ikeda-Suno, C.; Kuma, H.; et al. Crystal structure of the anion exchanger domain of human erythrocyte band 3. Science 2015, 350, 680-684. [CrossRef] [PubMed]

26. Tsuji, T.; Irimura, T.; Osawa, T. The carbohydrate moiety of band 3 glycoprotein of human erythrocyte membranes. Structures of lower molecular weight oligosaccharides. J. Biol. Chem. 1981, 256, 10497-10502. [PubMed]

27. Fukuda, M.; Dell, A.; Oates, J.E.; Fukuda, M.N. Structure of branched lactosaminoglycan, the carbohydrate moiety of band 3 isolated from adult human erythrocytes. J. Biol. Chem. 1984, 259, 8260-8273. [PubMed]

28. Chasis, J.A.; Mohandas, N. Red blood cell glycophorins. Blood 1992, 80, 1869-1879. [PubMed]

29. Cartron, J.-P.; Colin, Y.; Kudo, S.; Fukuda, M. Molecular Genetics of Human Erythrocyte Sialoglycoproteins Glycophorins A, B, C, and D; Springer: Boston, MA, USA, 1990; pp. 299-335. 
30. Blanchard, D. Human red cell glycophorins: Biochemical and antigenic properties. Transfus. Med. Rev. 1990, 4, 170-186. [CrossRef]

31. Furthmayer, H. Glycophorins A, B, and C: A family of sialoglycoproteins. Isolation and preliminary characterization of trypsin derived peptides. J. Supramol. Struct. 1978, 9, 79-95. [CrossRef] [PubMed]

32. De Isla, N.G.; Riquelme, B.D.; Rasia, R.J.; Valverde, J.R.; Stoltz, J.F. Quantification of glycophorin A and glycophorin B on normal human RBCs by flow cytometry. Transfusion 2003, 43, 1145-1152. [CrossRef] [PubMed]

33. Tomita, M.; Marchesi, V.T. Amino-acid sequence and oligosaccharide attachment sites of human erythrocyte glycophorin. Proc. Natl. Acad. Sci. USA 1975, 72, 2964-2968. [CrossRef] [PubMed]

34. Tomita, M.; Furthmayr, H.; Marchesi, V.T. Primary structure of human erythrocyte glycophorin A. Isolation and characterization of peptides and complete amino acid sequence. Biochemistry 1978, 17, 4756-4770. [CrossRef] [PubMed]

35. Bormann, B.-J.; Knowles, W.J.; Marchesi, V.T. Synthetic peptides mimic the assembly of transmembrane glycoproteins. J. Biol. Chem. 1989, 264, 4033-4037. [PubMed]

36. Lemmon, M.A.; Flanagan, J.M.; Hunt, J.F.; Adair, B.D.; Bormann, B.J.; Dempsey, C.E.; Engelman, D.M. Glycophorin A dimerization is driven by specific interactions between transmembrane $\alpha$-helices. J. Biol. Chem. 1992, 267, 7683-7689. [PubMed]

37. Brosig, B.; Langosch, D. The dimerization motif of the glycophorin A transmembrane segment in membranes: Importance of glycine residues. Protein Sci. 1998, 7, 1052-1056. [CrossRef] [PubMed]

38. MacKenzie, K.R.; Prestegard, J.H.; Engelman, D.M. A transmembrane helix dimer: Structure and implications. Science 1997, 276, 131-133. [CrossRef] [PubMed]

39. Smith, S.O.; Song, D.; Shekar, S.; Groesbeek, M.; Ziliox, M.; Aimoto, S. Structure of the transmembrane dimer interface of glycophorin A in membrane bilayers. Biochemistry 2001, 40, 6553-6558. [CrossRef] [PubMed]

40. Smith, S.O.; Eilers, M.; Song, D.; Crocker, E.; Ying, W.; Groesbeek, M.; Metz, G.; Ziliox, M.; Aimoto, S. Implications of threonine hydrogen bonding in the glycophorin A transmembrane helix dimer. Biophys. J. 2002, 82, 2476-2486. [CrossRef]

41. Anbazhagan, V.; Schneider, D. The membrane environment modulates self-association of the human GpA TM domain-Implications for membrane protein folding and transmembrane signaling. Biochim. Biophys. Acta 2010, 1798, 1899-1907. [CrossRef] [PubMed]

42. Shan, X.; Davis, J.H.; Chu, J.W.K.; Sharom, F.J. ${ }^{2}$ H-NMR investigation of DMPC/glycophorin bilayers. Biochim. Biophys. Acta 1994, 1193, 127-137. [CrossRef]

43. Thomas, D.B.; Winzler, R.J. Structural studies on human erythrocyte glycoproteins. Alkali-labile oligosaccharides. J. Biol. Chem. 1969, 244, 5943-5946. [PubMed]

44. Fukuda, M.; Lauffenburger, M.; Sasaki, H.; Rogers, M.E.; Dell, A. Structures of novel sialylated O-linked oligosaccharides isolated from human erythrocyte glycophorins. J. Biol. Chem. 1987, 262, 11952-11957. [PubMed]

45. Pisano, A.; Redmond, J.W.; Williams, K.L.; Gooley, A.A. Glycosylation sites identified by solid-phase Edman degradation: O-linked glycosylation motifs on human glycophorin A. Glycobiology 1993, 3, 429-435. [CrossRef] [PubMed]

46. Yoshima, H.; Furthmayr, H.; Kobata, A. Structures of the asparagine-linked sugar chains of glycophorin A. J. Biol. Chem. 1980, 255, 9713-9718. [PubMed]

47. Marchesi, V.T.; Furthmayr, H.; Tomita, M. The red cell membrane. Ann. Rev. Biochem. 1976, 45, 667-698. [CrossRef] [PubMed]

48. Furthmayr, H.; Tomita, M.; Marchesi, V.T. Fractionation of the major sialoglycopeptides of the human red blood cell membrane. Biochem. Biophys. Res. Commun. 1975, 65, 113-121. [CrossRef]

49. Marchesi, V.T.; Andrews, E.P. The use of lithium diiodosalicylate (LIS) to isolate glycoproteins from cell membranes. Science 1971, 174, 1247-1248. [CrossRef] [PubMed]

50. Furthmayr, H. Structural comparison of glycophorins and immunochemical analysis of genetic variants. Nature 1978, 271, 519-524. [CrossRef] [PubMed]

51. Siebert, P.D.; Fukuda, M. Isolation and characterization of human glycophorin A cDNA clones by a synthetic oligonucleotide approach: Nucleotide sequence and mRNA structure. Proc. Natl. Acad. Sci. USA 1986, 83, 1665-1669. [CrossRef] [PubMed] 
52. Siebert, P.D.; Fukuda, M. Molecular cloning of a human glycophorin B cDNA: Nucleotide sequence and genomic relationship to glycophorin A. Proc. Natl. Acad. Sci. USA 1987, 84, 6735-6739. [CrossRef] [PubMed]

53. Tate, C.G.; Tanner, M.J.A. Isolation of cDNA clones for human erythrocyte membrane sialoglycoproteins $\alpha$ and $\delta$. Biochem. J. 1988, 254, 743-750. [CrossRef] [PubMed]

54. Mattei, M.G.; Colin, Y.; Le Van Kim, C.; Mattei, J.F.; Cartron, J.-P. Localization of the gene for human erythrocyte glycophorin C to chromosome 2, q14-q21. Hum. Genet. 1986, 74, 420-422. [CrossRef] [PubMed]

55. Le Van Kim, C.; Colin, Y.; Blanchard, D.; Dahr, W.; London, J.; Cartron, J.-P. Gerbich blood group deficiency of the Ge:-1,-2,-3 and Ge:-1,-2, 3 types. Immunochemical study and genomic analysis with cDNA probes. Eur. J. Biochem. 1987, 165, 571-579. [PubMed]

56. Cartron, J.-P.; Le Van Kim, C.; Colin, Y. Glycophorin C and related glycophorins: Structure, function, and regulation. Semin. Hematol. 1993, 30, 152-168. [PubMed]

57. Dahr, W.; Beyreuther, K.; Kordowicz, M.; Krüger, J. N-terminal amino acid sequence of sialoglycoprotein D (glycophorin C) from human erythrocyte membranes. Eur. J. Biochem. 1982, 125, 57-62. [CrossRef] [PubMed]

58. Kudo, S.; Fukuda, M. Identification of a novel human glycophorin, glycophorin E, by isolation of genomic clones and complementary DNA clones utilizing polymerase chain reaction. J. Biol. Chem. 1990, 265, 1102-1110. [PubMed]

59. Vignal, A.; Rahuel, C.; London, J.; Zahar, B.C.; Schaff, S.; Hattab, C.; Okubo, Y.; Cartron, J.-P. A novel gene member of the human glycophorin A and B gene family. Eur. J. Biochem. 1990, 191, 619-625. [CrossRef] [PubMed]

60. Kudo, S.; Fukuda, M. Contribution of gene conversion to the retention of the sequence for M blood group type determinant in glycophorin E gene. J. Biol. Chem. 1994, 269, 22969-22974. [PubMed]

61. Onetti, R.; Baulida, J.; Bassols, A. Increased glucose transport in ras-transformed fibroblasts: A possible role for N-glycosylation of GLUT1. FEBS Lett. 1997, 407, 267-270. [CrossRef]

62. Counillon, L.; Pouysségur, J.; Reithmeier, R.A.F. The $\mathrm{Na}^{+} / \mathrm{H}^{+}$exchanger NHF-1 possesses N- and O-linked glycosylation restricted the first N-terminal extracellular domain. Biochemistry 1994, 33, 10463-10469. [CrossRef] [PubMed]

63. Tse, C.-M.; Levine, S.A.; Yun, C.H.C.; Khurana, S.; Donowitz, M. The plasma membrane $\mathrm{Na}^{+} / \mathrm{H}^{+}$exchanger 2 is an O-linked but not an N-linked sialoglycoprotein: Use of a polyclonal antibody to identify and characterize glycosylation. Biochemistry 1994, 33, 12954-12961. [CrossRef] [PubMed]

64. Orlowski, J.; Grinstein, S. Na+ $/ \mathrm{H}^{+}$exchangers of mammalian cells. J. Biol. Chem. 1997, 272, $22373-22376$. [CrossRef] [PubMed]

65. Denker, S.P.; Huang, D.C.; Orlowski, J.; Furthmayr, H.; Barber, D.L. Direct binding of the Na-H exchanger NHE1 to ERM proteins regulates the cortical cytoskeleton and cell shape independently of $\mathrm{H}^{+}$translocation. Mol. Cell 2000, 6, 1425-1436. [CrossRef]

66. Ponta, H.; Wainwright, D.; Herrlich, P. Molecules in focus The CD44 protein family. Int. J. Biochem. Cell Biol. 1998, 30, 299-305. [CrossRef]

67. Skelton, T.P.; Zeng, C.; Nocks, A.; Stamenkovic, I. Glycosylation provides both stimulatory and inhibitory effects on cell surface and soluble CD44 binding to hyaluronan. J. Cell Biol. 1998, 140, 431-446. [CrossRef] [PubMed]

68. Isacke, C.M.; Yarwood, H. The hyaluronan receptor, CD44. Int. J. Biochem. Cell Biol. 2002, 34, 718-721. [CrossRef]

69. Mawby, W.J.; Holmes, C.H.; Anstee, D.J.; Spring, F.A.; Tanner, M.J.A. Isolation and characterization of CD47 glycoprotein: A multispanning membrane protein which is the same as integrin-associated protein (IAP) and the ovarian tumour marker OA3. Biochem. J. 1994, 304, 525-530. [CrossRef] [PubMed]

70. Subramanian, S.; Boder, E.T.; Discher, D.E. Phylogenetic divergence of CD47 interactions with human signal regulatory protein $\alpha$ reveals locus of species specificity. Implications for the binding site. J. Biol. Chem. 2007, 282, 1805-1818. [CrossRef] [PubMed]

71. Anstee, D.J. Blood group-active surface molecules of the human red blood cell. Vox Sang. 1990, 58, 1-20. [CrossRef] [PubMed]

72. Grodecka, M.; Bertrand, O.; Karolak, E.; Lisowski, M.; Waśniowska, K. One-step immunopurification and lectinochemical characterization of the Duffy atypical chemokine receptor from human erythrocytes. Glycoconj. J. 2012, 29, 93-105. [CrossRef] [PubMed] 
73. Ryan, J.R.; Stoute, J.A.; Amon, J.; Dunton, R.F.; Mtalib, R.; Koros, J.; Owour, B.; Luckhart, S.; Wirtz, R.A.; Barnwell, J.W.; et al. Evidence for transmission of Plasmodium vivax among a Duffy antigen negative population in western Kenya. Am. J. Trop. Med. Hyg. 2006, 75, 575-581. [PubMed]

74. Daniels, G.; Khalid, G. Identification, by immunoblotting, of the structures carrying Lutheran and para-Lutheran blood group antigens. Vox Sang. 1989, 57, 137-141. [CrossRef] [PubMed]

75. Parson, S.F.; Mallinson, G.; Judson, P.A.; Anstee, D.J.; Tanner, M.J.; Daniels, G.L. Evidence that the Lub blood group antigen is located on red cell membrane glycoproteins of 85 and $78 \mathrm{kd}$. Transfussion 1987, 27, 61-63. [CrossRef]

76. Redman, C.M.; Avellino, G.; Pfeffer, S.R.; Mukherjee, T.K.; Nichols, M.; Rubinstein, P.; Marsh, W.L. Kell blood group antigens are part of a 93,000-dalton red cell membrane protein. J. Biol. Chem. 1986, 261, 9521-9525. [PubMed]

77. Jaber, A.; Blanchard, D.; Goossens, D.; Bloy, C.; Lambin, P.; Rouger, P.; Salmon, C.; Cartron, J.-P. Characterization of the blood group Kell (K1) antigen with a human monoclonal antibody. Blood 1989, 73, 1597-1602. [PubMed]

78. Lee, S.; Zambas, E.D.; Marsh, W.L.; Redman, C.M. Molecular cloning and primary structure of Kell blood group protein. Proc. Natl. Acad. Sci. USA 1991, 88, 6353-6357. [CrossRef] [PubMed]

79. Lee, S.; Russo, D.; Redman, C. Functional and structural aspects of the Kell blood group system. Transfus. Med. Rev. 2000, 14, 93-103. [CrossRef]

80. Yu, L.-C.; Twu, Y.-C.; Chou, M.-L.; Reid, M.E.; Gray, A.R.; Moulds, J.M.; Chang, C.-Y.; Lin, M. The molecular genetics of the human $I$ locus and molecular background explain the partial association of the adult $\mathrm{i}$ phenotype with congenital cataracts. Blood 2003, 101, 2081-2088. [CrossRef] [PubMed]

81. Huflejt, M.E.; Vuskovic, M.; Vasiliu, D.; Xu, H.; Obukhova, P.; Shilova, N.; Tuzikov, A.; Galanina, O.; Arun, B.; $\mathrm{Lu}, \mathrm{K}$; et al. Anti-carbohydrate antibodies of normal sera: Findings, surprises and challenges. Mol. Immunol. 2009, 46, 3037-3049. [CrossRef] [PubMed]

82. Beppu, M.; Kikugawa, K. Senescent cell antigens in the clearance of senescent cells. Seikagaku 1995, 67, 303-307. (In Japanese) [PubMed]

83. Reithmeier, R.A.F.; Casey, J.R.; Kalli, A.C.; Sansom, M.S.P.; Alguel, Y.; Iwata, S. Band 3, the human red cell chloride/bicarbonate anion exchanger (AE1, SLC4A1), in a structural context. Biochim. Biophys. Acta 2016, 1858, 1507-1532. [CrossRef] [PubMed]

84. Alper, S.L.; Kopito, R.R.; Libresco, S.M.; Lodish, H.F. Cloning and characterization of a murine band 3-related cDNA from kidney and from a lymphoid cell line. J. Biol. Chem. 1988, 263, 17092-17099. [PubMed]

85. Kopito, R.R.; Lee, B.S.; Simmons, D.M.; Lindsey, A.E.; Morgans, C.W.; Schneider, K. Regulation of intracellular pH by a neuronal homolog of the erythrocyte anion exchanger. Cell 1989, 59, 927-937. [CrossRef]

86. Casey, J.R.; Pirraglia, C.A.; Reithmeier, R.A.F. Enzymatic deglycosylation of human Band 3, the anion transport protein of the erythrocyte membrane. Effect on protein structure and transport properties. J. Biol. Chem. 1992, 267, 11940-11948. [PubMed]

87. Kay, M.M.B. Location of senescent cell antigen on band 3. Proc. Natl. Acad. Sci. USA 1984, 81, 5753-5757. [CrossRef] [PubMed]

88. Kay, M.M.B. Isolation of the phagocytosis-inducing IgG-binding antigen on senescent somatic cells. Nature 1981, 289, 491-494. [CrossRef] [PubMed]

89. Kay, M.M.B.; Goodman, S.R.; Sorensen, K.; Whitfield, C.L.; Wong, P.; Zaki, L.; Rudloff, V. Senescent cell antigen is immunologically related to band 3. Proc. Natl. Acad. Sci. USA 1983, 80, 1631-1635. [CrossRef] [PubMed]

90. Beppu, M.; Mizukami, A.; Nagoya, M.; Kikugawa, K. Binding of anti-band 3 autoantibody to oxidatively damaged erythrocytes. Formation of senescent antigen on erythrocyte surface by an oxidative mechanism. J. Biol. Chem. 1990, 265, 3226-3233. [PubMed]

91. Beppu, M.; Mizukami, A.; Nagoya, M.; Kikugawa, K. Generation of senescent antigen on erythrocytes by partial blocking of SH groups of the membrane proteins. J. Pharmacobio-Dyn. 1992, 15, 353-358. [CrossRef] [PubMed]

92. Beppu, M.; Mizukami, A.; Ando, K.; Kikugawa, K. Antigenic determinants of senescent antigen of human erythrocytes are located in sialylated carbohydrate chains of Band 3 glycoprotein. J. Biol. Chem. 1992, 267, 14691-14696. [PubMed] 
93. Ando, K.; Kikugawa, K.; Beppu, M. Involvement of sialylated poly-N-acetyllactosaminyl sugar chains of band 3 glycoprotein on senescent erythrocytes in anti-band 3 autoantibody binding. J. Biol. Chem. 1994, 269, 19394-19398. [PubMed]

94. Kay, M.M.B.; Marchalonis, J.J.; Hughes, J.; Watanabe, K.; Schluter, S.F. Definition of a physiologic aging autoantigen by using synthetic peptides of membrane protein band 3: Localization of the active antigenic sites. Proc. Natl. Acad. Sci. USA 1990, 87, 5734-5738. [CrossRef] [PubMed]

95. Lutz, H.U.; Gianora, O.; Nater, M.; Schweizer, E.; Stammler, P. Naturally occurring anti-band 3 antibodies bind to protein rather than to carbohydrate on band 3. J. Biol. Chem. 1993, 268, 23562-23566. [PubMed]

96. Blumenfeld, O.O.; Huang, C.-H. Molecular genetics of the glycophorin gene family, the antigens for MNSs blood groups: Multiple gene rearrangements and modulation of splice site usage result in extensive diversification. Hum. Mutat. 1995, 6, 199-209. [CrossRef] [PubMed]

97. Hamaguchi, H.; Cleve, H. Solubilization of human erythrocyte membrane glycoproteins and separation of the MN glycoprotein from a glycoprotein with I, S, and A activity. Biochim. Biophys. Acta 1972, 278, 271-280. [CrossRef]

98. Blumenfeld, O.O.; Zvilichovsky, B. Isolation of glycoproteins from red cell membranes using pyridine. Methods Enzymol. 1972, 28, 245-252.

99. Schulte, T.H.; Marchesi, V.T. Self-association of human erythrocyte glycophorin A. Appearance of low mobility bands on sodium dodecyl sulfate gels. Biochim. Biophys. Acta 1978, 508, 425-430. [CrossRef]

100. Furthmayr, H.; Marchesi, V.T. Subunit structure of human erythrocyte glycophorin A. Biochemistry 1976, 15, 1137-1144. [CrossRef] [PubMed]

101. Janado, M.; Azuma, J.; Onodera, K. Heterogeneity of a human erythrocyte membrane glycoprotein. J. Biochem. 1973, 74, 881-887. [PubMed]

102. Lemmon, M.A.; Flanagan, J.M.; Treutlein, H.R.; Zhang, J.; Engelman, D.M. Sequence specificity in the dimerization of transmembrane $\alpha$-helixes. Biochemistry 1992, 31, 12719-12725. [CrossRef] [PubMed]

103. Marton, L.S.G.; Garvin, J.E. Subunit structure of the major human erythrocyte glycoprotein: Depolymerization by heating ghosts with sodium dodecyl sulfate. Biochem. Biophys. Res. Commun. 1973, 52, 1457-1462. [CrossRef]

104. Tuech, J.K.; Morrison, M. Human erythrocyte membrane sialoglycoproteins: A study of interconversion. Biochem. Biophys. Res. Commun. 1974, 59, 352-360. [CrossRef]

105. Johe, K.K.; Smith, A.J.; Vengelen-Tyler, V.; Blumenfeld, O.O. Amino acid sequence of an $\alpha$ - $\delta$-glycophorin hybrid. A structure reciprocal to Sta $\delta$ - $\alpha$-glycophorin hybrid. J. Biol. Chem. 1989, 264, 17486-17493. [PubMed]

106. Merry, A.H.; Hodson, C.; Thomson, E.; Mallinson, G.; Anstee, D.J. The use of monoclonal antibodies to quantify the levels of sialoglycoproteins $\alpha$ and $\delta$ and variant sialoglycoproteins in human erythrocyte membranes. Biochem. J. 1986, 233, 93-98. [CrossRef] [PubMed]

107. Ada, G.L.; Stone, J.D. Electrophoretic studies of virus-red cell interaction: Mobility gradient of cells treated with viruses of the influenza group and the receptor-destroying enzyme of V. cholerae. Brit. J. Exptl. Pathol. 1950, 31, 263-274.

108. Dahr, W.; Beyreuther, K.; Steinbach, H.; Gielen, W.; Krüger, J. Structure of the Ss blood group antigens, II. A methionine/threonine polymorphism within the N-terminal sequence of the Ss glycoprotein. Hoppe-Seyler Z. Physiol. Chem. 1980, 361, 895-906. [CrossRef] [PubMed]

109. Prohaska, R.; Koerner, T.A.W., Jr.; Armitage, I.M.; Furthmayr, H. Chemical and carbon-13 nuclear magnetic resonance studies of the blood group $\mathrm{M}$ and $\mathrm{N}$ active sialoglycopeptides from human glycophorin $\mathrm{A}$. J. Biol. Chem. 1981, 256, 5781-5791. [PubMed]

110. Pang, A.J.; Reithmeier, R.A.F. Interaction of anion exchanger 1 and glycophorin A in human erythroleukaemic K562 cells. Biochem. J. 2009, 421, 345-356. [CrossRef] [PubMed]

111. Anstee, D.J.; Ridgwell, K.; Tanner, M.J.A.; Daniels, G.L.; Parsons, S.F. Individuals lacking the Gerbich blood-group antigen have alterations in the human erythrocyte membrane sialoglycoproteins $\beta$ and $\gamma$. Biochem. J. 1984, 221, 97-104. [CrossRef] [PubMed]

112. Dahr, W.; Moulds, J.; Baumeister, G.; Moulds, M.; Kiedrowski, S.; Hummel, M. Altered membrane sialoglycoproteins in human erythrocytes lacking the Gerbich blood group antigens. Biol. Chem. Hoppe-Seyler 1985, 366, 201-211. [CrossRef] [PubMed]

113. Lisowska, E. Antigenic properties of human glycophorins-An update. In The Molecular Immunology of Complex Carbohydrates—2; Springer: Boston, MA, USA, 2001; pp. 155-169. 
114. Takasaki, S.; Kobata, A. Chemical characterization and distribution of ABO blood group active glycoprotein in human erythrocyte membrane. J. Biol. Chem. 1976, 251, 3610-3615. [PubMed]

115. Wilczyńska, Z.; Miller-Podraza, H.; Kościelak, J. The contribution of different glycoconjugates to the total ABH blood group activity of human erythrocytes. EFBS Lett. 1980, 112, 277-279.

116. Podbielska, M.; Fredriksson, S.-Å.; Nilsson, B.; Lisowska, E.; Krotkiewski, H. ABH blood group antigens in O-glycans of human glycophorin A. Arch. Biochem. Biophys. 2004, 429, 145-153. [CrossRef] [PubMed]

117. Sueyoshi, S.; Tsuji, T.; Osawa, T. Carbohydrate-binding specificities of five lectins that bind to O-glycosyl-linked carbohydrate chains. Quantitative analysis by frontal-affinity chromatography. Carbohydr. Res. 1988, 178, 213-224. [CrossRef]

118. Krotkiewska, B.; Pasek, M.; Krotkiewski, H. Interaction of glycophorin A with lectins as measured by surface plasmon resonance (SPR). Acta Biochim. Pol. 2002, 49, 481-490. [PubMed]

119. Anderson, R.; Paquette, S.; Lovrien, R. Lectin-erythrocyte interaction with external transmembrane glycophorin saccharides controlling membrane internal cytoskeleta. J. Agric. Food Chem. 2002, 50, 6599-6604. [CrossRef] [PubMed]

120. Ellens, H.; Bentz, J.; Mason, D.; Zhang, F.; White, J.M. Fusion of influenza hemagglutinin-expressing fibroblasts with glycophorin-bearing liposomes: Role of hemagglutinin surface density. Biochemistry 1990, 29, 9697-9707. [CrossRef] [PubMed]

121. Kanaseki, T.; Kawasaki, K.; Murata, M.; Ikeuchi, Y.; Ohnishi, S. Structural features of membrane fusion between influenza virus and liposome as revealed by quick-freezing electron microscopy. J. Cell Biol. 1997, 137, 1041-1056. [CrossRef] [PubMed]

122. Suzuki, Y.; Suzuki, T.; Matsumoto, M. Isolation and characterization of receptor sialoglycoprotein for hemagglutinating virus of Japan (Sendai virus) from bovine erythrocyte membrane. J. Biochem. 1983, 93, 1621-1633. [CrossRef] [PubMed]

123. Wybenga, L.E.; Epand, R.F.; Nir, S.; Chu, J.W.K.; Sharom, F.J.; Flanagan, T.D.; Epand, R.M. Glycophorin as a receptor for Sendai virus. Biochemistry 1996, 35, 9513-9518. [CrossRef] [PubMed]

124. Templeton, T.J.; Keister, D.B.; Muratova, O.; Procter, J.; Kaslow, D.C. Adherence of erythrocytes during exflagellation of Plasmodium falciparum microgametes is dependent on erythrocyte surface sialic acid and glycophorins. J. Exp. Med. 1998, 187, 1599-1609. [CrossRef] [PubMed]

125. Pasvol, G. How many pathways for invasion of the red blood cell by the malaria parasite? Trends. Parasitol. 2003, 19, 430-432. [CrossRef] [PubMed]

126. Lobo, C.-A. Babesia divergens and Plasmodium falciparum use common receptors, glycophorins A and B, to invade the human red blood cell. Infect. Immun. 2005, 73, 649-651. [CrossRef] [PubMed]

127. Ghislaine Mayer, D.C.; Jiang, L.; Achur, R.N.; Kakizaki, I.; Gowda, D.C.; Miller, L.H. The glycophorin C $\mathrm{N}$-linked glycan is a critical component of the ligand for the Plasmodium falciparum erythrocyte receptor BAEBL. PNAS 2006, 103, 2358-2362. [CrossRef] [PubMed]

128. Cortajarena, A.L.; Goñi, F.M.; Ostolaza, H. Glycophorin as a receptor for Escherichia coli $\alpha$-hemolysin in erythrocytes. J. Biol. Chem. 2001, 276, 12513-12519. [CrossRef] [PubMed]

129. Hirst, G.K. The agglutination of red cells by allantoic fluid of chick embryos infected with influenza virus. Science 1941, 94, 22-23. [CrossRef] [PubMed]

130. Cochet, S.; Volet, G.; Cartron, J.-P.; Bertrand, O. New procedures for glycophorin A purification with high yield and high purity. J. Chromatogr. B 2001, 750, 109-119. [CrossRef]

131. Lee, S.; Lu, W. Using elastic light scattering of red blood cells to detect infection of malaria parasite. IEEE Trans. Biomed. Eng. 2012, 59, 150-155. [PubMed]

132. Giger, K.; Habib, I.; Ritchie, K.; Low, P.S. Diffusion of glycophorin A in human erythrocytes. Biochim. Biophys. Acta 2016, 1858, 2839-2845. [CrossRef] [PubMed]

133. Yiangou, L.; Montandon, R.; Modrzynska, K.; Rosen, B.; Bushell, W.; Hale, C.; Billker, O.; Rayner, J.C.; Pance, A. A stem cell strategy identifies glycophorin $\mathrm{C}$ as a major erythrocyte receptor for the rodent malaria parasite Plasmodium berghei. PLoS ONE 2016, 11, e0158238. [CrossRef] [PubMed]

134. Hasssoun, H.; Hanada, T.; Lutchman, M.; Sahr, K.E.; Palek, J.; Hanspal, M.; Chishti, A.H. Complete deficiency of glycophorin A in red blood cells from mice with targeted inactivation of the band 3 (AE1) gene. Blood 1998, 91, 2146-2151.

135. Lesley, J.B.; Groves, J.D.; Okubo, Y.; Thilaganathan, B.; Tanner, J.A. Altered band 3 structure and function in glycophorin A- and B-deficient $\left(\mathrm{M}^{\mathrm{k}} \mathrm{M}^{\mathrm{k}}\right)$ red blood cells. Blood 1994, 84, 916-922. 
136. Hamaguchi, H.; Cleve, H. Solubilization and comparative analysis of mammalian erythrocyte membrane glycoproteins. Biochem. Biophys. Res. Commun. 1972, 47, 459-464. [CrossRef]

137. Ballas, S.K. Comparative distribution of glyceraldehyde 3-phosphate dehydrogenase activity in human, guinea-pig, rabbit and mouse erythrocytes. Comp. Biochem. Physiol. B 1987, 87, 837-842. [CrossRef]

138. Matsuyama, R.; Ueda, T.; Inoue, F. SDS-PAGE analysis of membrane proteins on domestic cat (Felis catus) erythrocytes. Med. Biol. 1999, 138, 79-82. (In Japanese)

139. Fukuda, K.; Tomita, M.; Hamada, A. Isolation and characterization of alkali-labile oligosaccharide units from horse glycophorin. J. Biochem. 1980, 87, 687-693. [CrossRef] [PubMed]

140. Fukuda, K.; Kawashima, I.; Tomita, M.; Hamada, A. Structural studies of the acidic oligosaccharide units from bovine glycophorin. Biochim. Biophys. Acta 1982, 717, 278-288. [CrossRef]

141. Kawashima, I.; Fukuda, K.; Tomita, M.; Hamada, A. Isolation and characterization of alkali-labile oligosaccharide units from porcine erythrocyte glycophorin. J. Biochem. 1982, 91, 865-872. [CrossRef] [PubMed]

142. Klimas, N.G.; Caldwell, K.E.; Whitney, P.L.; Fletcher, M.A. Comparison of receptor properties of erythrocyte membrane glycoproteins. Dev. Comp. Immunol. 1981, 6, 765-774.

143. Yamashita, T.; Murayama, J.; Utsumi, H.; Hamada, A. Structural studies of O-glycosidic oligosaccharide units of dog erythrocyte glycophorin. Biochim. Biophys. Acta 1985, 839, 26-31. [CrossRef]

144. Angel, A.-S.; Grönberg, G.; Krotkiewski, H.; Lisowska, E.; Nilsson, B. Structural analysis of the N-linked oligosaccharides from murine glycophorin. Arch. Biochem. Biophys. 1991, 291, 76-88. [CrossRef]

145. Murayama, J.-I.; Utsumi, H.; Hamada, A. Amino acid sequence of monkey erythrocyte glycophorin MK. Its amino acid sequence has a striking homology with that of human glycophorin A. Biochim. Biophys. Acta 1989, 999, 273-280. [CrossRef]

146. Krotkiewski, H. The structure of glycophorins of animal erythrocytes. Glycoconj. J. 1988, 5, 35-48. [CrossRef]

147. Dockham, P.A.; Vidaver, G.A. Comparison of human and pigeon erythrocyte membrane proteins by one-and two-dimensional gel electrophoresis. Comp. Biochem. Physiol. 1987, 87B, 171-177. [CrossRef]

148. Weise, M.J.; Ingram, V.M. Proteins and glycoproteins of membranes from developing chick red cells. J. Biol. Chem. 1976, 251, 6667-6673. [PubMed]

149. Caldwell, A.B. Proteins of the turkey erythrocyte membrane. Biochemistry 1976, 15, 2711-2718. [CrossRef] [PubMed]

150. Romano, L.; Passow, H. Characterization of anion transport system in trout red blood cell. Am. J. Physiol. 1984, 246, C330-C338. [PubMed]

151. Jay, D.G. Characterization of the chicken erythrocyte anion exchange protein. J. Biol. Chem. 1983, 258, 9431-9436. [PubMed]

152. Michel, F.; Rudloff, V. Isolation and characterization of the rainbow trout erythrocyte band-3 protein. FEBS J. 1989, 181, 181-187. [CrossRef]

153. Hübner, S.; Michel, F.; Rudloff, V.; Appelhans, H. Amino acid sequence of band-3 protein from rainbow trout erythrocytes derived from cDNA. Biochem. J. 1992, 285, 17-23. [CrossRef] [PubMed]

154. Jackson, R.C. The exterior surface of the chicken erythrocyte. J. Biol. Chem. 1975, 250, 617-622. [PubMed]

155. Duk, M.; Krotkiewski, H.; Stasyk, T.V.; Lutsik-Kordovsky, M.; Syper, D.; Lisowska, E. Isolation and characterization of glycophorin from nucleated (chicken) erythrocytes. Arch. Biochem. Biophys. 2000, 375, 111-118. [CrossRef] [PubMed]

156. Aoki, T.; Fukai, M.; Ueno, R. Glycoproteins in red cell membranes from carp and rainbow trout. Fish. Sci. 1996, 62, 498-499. [CrossRef]

157. Aoki, T.; Chimura, K.; Nakao, N.; Mizuno, Y. Isolation and characterization of glycophorin from carp red blood cell membranes. Membranes 2014, 4, 491-508. [CrossRef] [PubMed]

158. Aoki, T.; Inoue, T. Glycophorin in red blood cell membranes of healthy and diseased carp, Cyprinus carpio L. J. Fish Dis. 2011, 34, 573-576. [CrossRef] [PubMed]

159. Aoki, T.; Chimura, K.; Sugiura, H.; Mizuno, Y. Structure of a sialo-oligosaccharide from glycophorin in carp red blood cell membranes. Membranes 2014, 4, 764-777. [CrossRef] [PubMed]

160. Araki, T.; Aoki, T.; Kitamikado, M. Isolation and identification of a $\beta$-1,3-xylanase-producing bacterium. Nippon Suisan Gakkaishi 1987, 53, 2077-2081. [CrossRef] 
161. Uchida, Y. Application of Chitin, Chitosan; Chitin, Chitosan research association, Ed.; Gihodo Shuppan Co., Ltd.: Tokyo, Japan, 1990; pp. 71-98. (In Japanese)

162. Wilson, M.; Bengtén, E.; Miller, N.W.; Clem, L.W.; Du Pasquier, L.; Warr, G.W. A novel chimeric Ig heavy chain from a teleost fish shares similarities to IgD. Proc. Natl. Acad. Sci. USA 1997, 94, 4593-4597. [CrossRef] [PubMed] 